\title{
Effect of Thyroid Status on Insulin Action in Rat Adipocytes and Skeletal Muscle
}

\author{
Michael P. Czech, Craig C. Malbon, Keith Kerman, Wendy Gitomer, and \\ Paul F. PILCH, Section of Physiological Chemistry, Division of Biology \\ and Medicine, Brown University, Providence, Rhode Island 02912
}

A B S T RACT Isolated adipocytes and soleus muscles prepared from mature rats, rendered hypothyroid by a low iodine diet and propylthiouracil, markedly resisted the ability of insulin to increase glucose utilization. In adipocytes, the sum of basal $\mathrm{D}-\left(1-{ }^{14} \mathrm{C}\right)$ glucose conversion to $\mathrm{CO}_{2}$, glyceride-glycerol, and fatty acid was unaltered by hypothyroidism, although conversion to fatty acid was decreased. The response of each of these metabolic pathways to insulin at all concentrations tested was greatly diminished in hypothyroid rat adipocytes. 3-O-Methylglucose transport rates in the presence of insulin were not significantly different in adipocytes from hypothyroid as compared with euthyroid rats, although basal transport rates were significantly higher in the hypothyroid state. Lipolysis and cyclic AMP accumulation in adipocytes from hypothyroid rats in response to theophylline were markedly diminished compared with euthyroid controls, but insulin was about as effective in inhibiting lipolysis in these cells as in those derived from euthyroid animals. The binding of ${ }^{125}$ I-insulin to adipocytes at several hormone concentrations was also shown to be unaffected by hypothyroidism.

In soleus muscle, basal glucose conversion to $\mathrm{H}_{2} \mathrm{O}$ and glycogen was unaltered in the hypothyroid state, whereas insulin action on these pathways was markedly inhibited. The decrease in muscle insulin responsiveness was less marked than that observed in adipocytes. Uptake of either 2-deoxyglucose or Larabinose in the presence or absence of insulin was similar in soleus muscles derived from euthryoid vs. hypothyroid rats. Similarly, insulin action on the conversion of soleus muscle glycogen synthase $D$ to the $I$ form in the absence of glucose was unaltered

Dr. Czech is the recipient of Research Career Development Award AM-00249 from the U. S. Public Health Service. Dr. Malbon's present address is Department of Pharmacological Sciences, Health Sciences Center, State University of New York at Stony Brook, Stony Brook, New York. 11794.

Received for publication 18 January 1980 and in revised form 12 May 1980. by hypothyroidism. We conclude that (a) hypothyroidism in mature rats leads to a marked decrease in the responsiveness of glucose metabolism in adipocytes and skeletal muscle to insulin; $(b)$ no detectable impairment of the membrane insulin effector systems that mediate the regulation of adipocyte hexose transport and glycogen synthase is caused by hypothyroidism in this animal model; and $(c)$ the cellular defect that leads to apparent insulin resistance of adipocyte and soleus muscle glucose utilization resides at the level of one or more intracellular enzymes involved in glucose catabolism.

\section{INTRODUCTION}

Recent studies by Danforth et al. $(1,2)$ have uncovered a positive relationship between carbohydrate intake and circulating levels of triiodothyronine in humans. These data are consistent with the possibility that thyroid hormone regulates the capacity of tissues to use carbohydrate. Little information is available on the influence of thyroid hormone on carbohydrate metabolism in the peripheral, insulin-sensitive tissues, fat and muscle.

The present studies were thus designed to investigate a possible effect of thyroid hormone on glucose use in these tissues. In addition, the influence of thyroid status on the responsiveness of these tissues to insulin action on hexose transport and metabolism was assessed. The data demonstrate a striking deficit in the capacity of fat and muscle derived from hypothyroid rats to use glucose in the presence of insulin. This decreased response of glucose use to insulin in hypothyroid rats appears to be related to decreased activity of intracellular enzymes involved in glucose catabolism rather than a defective insulin effector system.

\section{METHODS}

Animals. Female Sprague-Dawley rats (Charles River CD strain, Charles River Breeding Laboratories, Inc., Wilmington, 
Mass.) were used in this study. Rats (150-175 g at start) were rendered hypothyroid by maintenance on an iodine-deficient diet 17700, United States Biochemical Corp., Cleveland, Ohio), and drinking water contained $0.00625 \% 6-\mathrm{N}$-propyl2-thiouracil for 21-24 d. This protocol has been shown to lead reproducibly to a hypothyroid state in rats as determined by circulating thyroid hormone measurements (35). Control rats were littermates or rats of the same weight as the experimental rats and were maintained on tap water and the same test diet, to which normal iodine had been added by the commercial supplier. At sacrifice, control rats weighed $258 \pm 4 \mathrm{~g}$ and hypothyroid rats weighed $231 \pm 5 \mathrm{~g}$. An additional group of rats was rendered hypothyroid as above and then given $30 \mu$ g triiodothyronine/ $100 \mathrm{~g}$ body wt daily for $4 \mathrm{~d}$ while remaining on the iodine-deficient diet and the 6-N-propyl-2thiouracil. Fat cell size was unaltered by any of the conditions used here.

Isolation of fat cells. White fat cells were obtained by enzymatic digestion of parametrial adipose tissue according to the procedure of Rodbell (6). Pooled adipose tissue from one to three rats was minced with scissors and placed in small plastic bottles. Each bottle, with 3-10 $\mathrm{g}$ of tissue and $10 \mathrm{ml}$ of Krebs-Ringer phosphate buffer containing $3 \%$ albumin and $1 \mathrm{mg} / \mathrm{ml}$ of crude collagenase (clostridium histolyticum, Worthington Biochemical Corp., Freehold, N. J., lot CLS 46E 168P), was incubated for $60 \mathrm{~min}$ at $37^{\circ} \mathrm{C}$. At the end of $60 \mathrm{~min}$ digestion, cells were filtered through one layer of nylon chiffon and washed twice with the albumin buffer. The number of fat cells was estimated as described by Gliemann (7).

Cyclic AMP assay. Cyclic AMP accumulation was measured in cells plus medium after a $0.2-\mathrm{ml}$ aliquot of cells plus medium, in duplicate, was extracted from $1 \mathrm{ml}$ of incubation volume and added to tubes on ice containing $20 \mu \mathrm{l}$ of $2 \mathrm{~N}$ $\mathrm{HCl}$. The tubes were then placed in a boiling water bath for $1 \mathrm{~min}$. The tubes were allowed to cool before $10 \mu \mathrm{l}$ of $4 \mathrm{~N}$ $\mathrm{NaOH}$ was added. The contents of the tubes were mixed and centrifuged before removal of $20-\mu \mathrm{l}$ aliquots for determination of cyclic AMP. In each experiment, no more than $50 \mathrm{mg}$ of fat cells were incubated per milliliter of medium, which means that the 20- $\mu$ l aliquots taken for cyclic AMP analysis represented $<1 \mathrm{mg}$ of fat cells. Cyclic AMP release to the medium at the end of the incubation was determined just before removing the $0.2-\mathrm{ml}$ aliquots of cells plus medium. The cyclic AMP standards were prepared in incubation medium containing albumin, which was treated in the same manner as the unknown samples, by adding acid and then boiling and neutralizing. The assay for cyclic AMP was done by a modification of the Gilman (8) protein kinase binding procedure. The cyclic AMP binding protein used in this assay was from the $10,000 \mathrm{~g}_{\max }$ supernatant fraction of homogenized bovine adrenal glands and the assay was conducted as described by Brown et al. (9) to eliminate possible interference by ATP.

Assay of fat cell hexose transport. Isolated adipocytes (1-3 $\times 10^{5}$ cells/tube) were incubated in plastic culture tubes containing $0.2 \mathrm{ml} \mathrm{Krebs-Ringer} \mathrm{phosphate} \mathrm{buffer} \mathrm{with} 4 \%$ albumin at $37^{\circ} \mathrm{C}$. Insulin was present at the indicated concentrations or was absent from the incubation medium. Transport was initiated with the addition of $10 \mu$ l of a solution containing $\left[3-\mathrm{O}_{-}{ }^{3} \mathrm{H}\right]$ methylglucose $(4-6 \mu \mathrm{Ci} /$ tube). The labeled hexose was dissolved in isotonic saline before addition. The tubes were immediately shaken vigorously by hand and incubated at $37^{\circ} \mathrm{C}$. After $10 \mathrm{~s}$, transport was stopped by addition of $3 \mathrm{ml}$ of ice-cold Krebs-Ringer phosphate buffer containing $0.1 \%$ albumin to the cells, then poured onto the center of the glass fiber filters under vacuum. It was crucial that the filters first be wetted (routinely $10 \mathrm{~s}$ before cells are poured) with albumin buffer (0.3-0.5\% albumin) and that the cold buffer containing cells and labeled hexose be aspirated through the filter before spreading to its edges and contaminating the glass of the filter apparatus (Millipore Corp., Bedford, Mass.). The cells were immediately washed by rapidly decanting $6 \mathrm{ml}$ of ice-cold Krebs-Ringer phosphate buffer containing $0.1 \%$ albumin onto the filters. The total time taken to filter and wash the cells was $<15 \mathrm{~s}$. Dried filters were subjected to liquid scintillation spectrophotometry in $4 \mathrm{ml}$ of scintillant containing $33 \% \mathrm{vol} / \mathrm{vol}$ Triton $\mathrm{X}$ 100 in toluene with 4 g/liter of Omnifluor (New England Nuclear, Boston, Mass.). Net uptake of label is the amount of radioactivity accumulated at a given time minus the radioactivity bound on filters containing cells to which labeled 3-O-methylglucose and $3 \mathrm{ml}$ of cold buffer were added together.

Assay of fat cell glucose utilization and glycerol release. Isolated fat cells $\left(3 \times 10^{5}\right.$ cells/tube $)$ were incubated in plastic culture tubes containing Krebs-Ringer phosphate buffer with $4 \%$ albumin at $37^{\circ} \mathrm{C}$. Insulin was present at the indicated concentrations or was absent from the incubation medium. The reaction was begun by addition of $\mathrm{D}-\left[1-{ }^{14} \mathrm{C}\right] \mathrm{glucose}(0.2$ $\mu \mathrm{Ci} /$ tube) and stopped after $60 \mathrm{~min}$ by the addition of 0.2 $\mathrm{ml}$ of $0.5 \mathrm{M} \mathrm{H}_{2} \mathrm{SO}_{4}$. Glucose conversion to $\mathrm{CO}_{2}$ and glycerol release were determined as described by Fain et al. (10).

Assay of ${ }^{125} \mathrm{I}$-insulin binding to fat cells. Fat cells (5 $\times 10^{5}$ cells/tube) were incubated in plastic culture tubes containing $0.4 \mathrm{ml}$ Krebs-Ringer phosphate buffer with $4 \%$ albumin at $25^{\circ} \mathrm{C}$. Unlabeled and ${ }^{125} \mathrm{I}$-insulin (New England Nuclear) were added at the indicated total concentrations for the 40 -min incubation. At the end of this period, total bound insulin was assayed by the same filtration procedure described for the assay of 3-O-methylglucose uptake. Nonspecific insulin binding was estimated from levels of ${ }^{125}$ I-insulin remaining bound to the fat cells in the presence of a supermaximal dose $(10 \mu \mathrm{g} / \mathrm{ml})$ of unlabeled insulin. These values were subtracted from other experimental values to determine specific binding.

Soleus muscle isolation and assay of glucose metabolism and transport. Soleus muscles were removed from decapitated rats as previously described in detail by LeMarchand et al. (11). The muscle was tied taut across a miniature device shaped like a horseshoe constructed with stainless steel wire, and tied muscles were incubated in the bottom of flat-bottomed vessels containing $2 \mathrm{ml}$ of Krebs-Ringer bicarbonate buffer ( $\mathrm{pH} 7.4$ ) containing $2 \%$ bovine serum albumin. The muscles were continually gassed $\left(\mathrm{O}_{2}: \mathrm{CO}_{2}, 95: 5\right)$ through rubber stoppers that sealed the vessels. In a typical experiment, the muscles were incubated with or without the indicated concentration of insulin for 30-40 min before addition of $5 \mathrm{mM}$ D- $\left[5^{-3} \mathrm{H}\right]$ glucose. The muscles were incubated for an additional $15 \mathrm{~min}$ and then assayed for labeled glycogen (12). Incorporation of label into $\mathrm{H}_{2} \mathrm{O}$ in the medium was assayed as an index of glycolytic flux as previously described (10). The activity of the initial steps in glucose utilizationtransport and phosphorylation-were estimated using 2deoxyglucose. Soleus muscles were incubated with $2-\left[{ }^{3} \mathrm{H}\right]-$ deoxyglucose at $0.2 \mathrm{mM}$ for $15 \mathrm{~min}$ subsequent to incubation in the presence of $2 \mathrm{mM}$ pyruvate with or without insulin for $30 \mathrm{~min}$. The muscles were then quickly rinsed in ice-cold Krebs-Ringer bicarbonate buffer and dissolved in $0.5 \mathrm{ml}$ of $1 \mathrm{~N}$ $\mathrm{NaOH}$ before monitoring an aliquot by liquid scintillation spectrophotometry. A similar assay condition was used for the assay of arabinose uptake.

\section{RESULTS}

Fig. 1 illustrates the pattern of $\mathrm{D}-\left[1-{ }^{14} \mathrm{C}\right]$ glucose metabolism in isolated fat cells prepared from normal 
and hypothyroid rats. In both groups of cells, production of labeled glyceride-glycerol and $\mathrm{CO}_{2}$ greatly exceeded fatty acid synthesis. No significant difference between cell types was found in basal $\mathrm{D}-\left[1-^{-14} \mathrm{C}\right]$ glucose conversion to $\mathrm{CO}_{2}$ and glyceride-glycerol, but a significant decrease in labeled fatty acid formation in cells from hypothyroid rats was observed. A key observation was the markedly decreased effects of insulin to stimulate $\mathrm{D}-\left[1-{ }^{14} \mathrm{C}\right]$ glucose to all these metabolites tested. This difference was significant $(P<0.05$ for all valves) at all concentrations of hormone tested (Fig. 1).

To evaluate whether the decreased responsiveness of fat cells from hypothyroid rats was due to one or more intracellular defects or to alterations in the insulin effector system, glucose metabolism was determined at various glucose concentrations. It is thought that fat cell glucose utilization rates increasingly reflect intracellular enzyme activity, rather than hexose transport activity, as the medium glucose concentration is increased $(14,15)$. A defect in hexose transport activa-

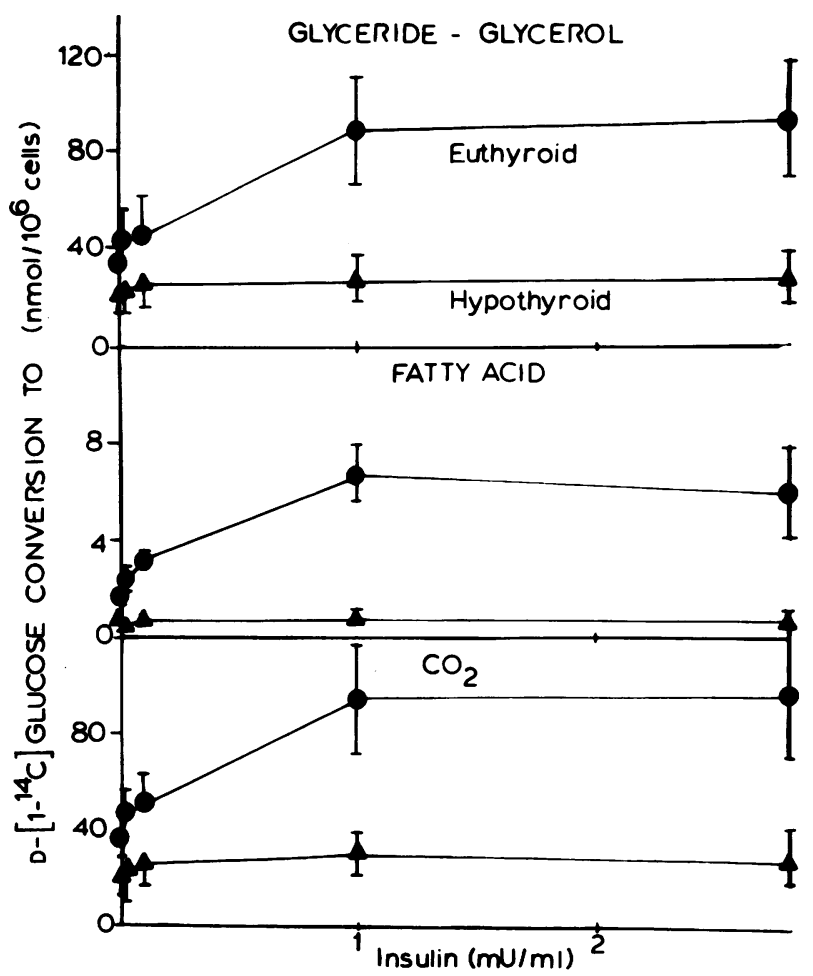

Figure 1 Response of glucose metabolism in euthyroid and hypothyroid rat fat cells to submaximal and maximal doses of insulin. Fat cells from euthyroid and hypothyroid rats were incubated in $1 \mathrm{ml}$ Krebs-Ringer phosphate buffer at $37^{\circ} \mathrm{C}$ containing $4 \%$ albumin and in the presence of the indicated concentrations of insulin for $1 \mathrm{~h} . \mathrm{D}-\left[1-{ }^{14} \mathrm{C}\right]$ glucose was present at a final concentration of $270 \mu \mathrm{M}$ and its conversion to carbon dioxide $\left(\mathrm{CO}_{2}\right)$, fatty acids, and glyceride-glycerol was measured. The values for $\mathrm{CO}_{2}$, fatty acid, and glyceride-glycerol represent the nanomoles of glucose incorporated $\pm S E$ in four paired experiments performed on different days. tion by insulin might therefore be less markedly expressed when cells are incubated at $20 \mathrm{mM}$ glucose compared with $0.5 \mathrm{mM}$ glucose. Table I shows that basal $\mathrm{D}-\left[1-{ }^{14} \mathrm{C}\right]$ glucose conversion to total lipids was not significantly different between cell types at all glucose concentrations tested, in accord with the data in Fig. 1. However, the nanomoles of labeled glucose converted into lipids in the presence of insulin were greatly decreased in cells from hypothyroid rats compared with control cells at all concentrations of medium glucose. No significant increase in glucose conversion to total lipids due to insulin was observed in the former cells at medium glucose concentrations of $5 \mathrm{mM}$ (Table I). The decrease in glucose metabolism observed in adipocytes from hypothyroid rats at both the low and high glucose concentrations in the presence of insulin was significant $(P<0.05)$. Similar observations were made for glucose oxidation to $\mathrm{CO}_{2}$ (not shown).

These data are consistent with the concept that intracellular metabolic capacity is already saturated in these cells in the absence of insulin. To test this hypothesis directly, estimated initial $\left[3-\mathrm{O}-{ }^{3} \mathrm{H}\right]$ methylglucose uptake rates were monitored in fat cells from euthyroid or hypothyroid rats (Fig. 2). In contrast to the lack of effect of the hypothryoid state on basal fat cell glucose use basal[3-O- $\left.{ }^{3} \mathrm{H}\right]$ methylglucose transport during a 10-s period was significantly increased in fat cells from hypothyroid rats. Insulin increased $\left[3-\mathrm{O}-{ }^{3} \mathrm{H}\right]$ methylglucose transport in both cell types in a dose-dependent manner that was maximal at $\sim 100 \mu \mathrm{U} / \mathrm{ml}$ insulin. No difference in the insulin-stimulated rates of hexose transport activity could be observed between cell types when maximal insulin concentrations were employed. Thus, D-glucose transport system activity of cells from hypothyroid rats was equal to or greater than that from euthyroid rats under all conditions tested, but glucose utilization in the former cell type was markedly decreased in the presence of insulin (Fig. 1 and Table I).

It is not clear from the data presented in Fig. 2 whether insulin action itself is impaired in the hypothyroid state. The apparent decreased percent activation of hexose transport by insulin in fat cells from hypothyroid animals may simply be due to an "insulinlike" effect of the thyroid hormone deficiency. Alternatively, hypothyroidism might be increasing the number of insulin-responsive hexose transport systems per cell as well as impairing insulin responsiveness. To evaluate this question, we studied two other aspects of insulin action in fat cells from euthyroid and hypothyroid rats: $(a)$ insulin-receptor interaction and $(b)$ inhibition of lipolysis. Table II illustrates the binding of ${ }^{125}$ I-insulin to such fat cells at concentrations of the hormone that range from 0.2 to $1.6 \times 10^{3} \mathrm{nM}$. No significant differences in the binding of ${ }^{125}$ I-insulin to these cell types was observed.

The data in Table III illustrate the effectiveness 
TABLE I

Effects of Increasing Glucose Concentrations on Decreased Glucose Metabolism Due to Hypothyroid State

\begin{tabular}{|c|c|c|c|c|}
\hline \multirow[b]{2}{*}{ Condition } & \multirow[b]{2}{*}{$\begin{array}{c}\text { Glucose } \\
\text { concentration }\end{array}$} & \multicolumn{3}{|c|}{ D- $\left[1-{ }^{14} \mathrm{C}\right]$ Glucose conversion to total lipids } \\
\hline & & Euthyroid & Hypothyroid & $\begin{array}{c}\text { Mean incremen } \\
\text { due to } \\
\text { hypothyroid } \\
\text { state }\end{array}$ \\
\hline & $m M$ & \multicolumn{3}{|c|}{ nmol/g fat cells } \\
\hline $\begin{array}{l}\text { Control } \\
+ \text { Insulin }(2.4 \mathrm{mU} / \mathrm{ml})\end{array}$ & $\begin{array}{l}0.5 \\
0.5\end{array}$ & $\begin{array}{l}132 \pm 29 \\
319 \pm 33\end{array}$ & $\begin{array}{l}168 \pm 54 \\
236 \pm 34\end{array}$ & $\begin{array}{l}36 \pm 25 \\
-82 \pm 4\end{array}$ \\
\hline $\begin{array}{l}\text { Control } \\
+ \text { Insulin }(2.4 \mathrm{mU} / \mathrm{ml})\end{array}$ & $\begin{array}{l}5 \\
5\end{array}$ & $\begin{array}{l}218 \pm 36 \\
538 \pm 131\end{array}$ & $\begin{array}{l}222 \pm 48 \\
278 \pm 42\end{array}$ & $\begin{array}{r}4 \pm 15 \\
-261 \pm 80\end{array}$ \\
\hline $\begin{array}{l}\text { Control } \\
+ \text { Insulin }(2.4 \mathrm{mU} / \mathrm{ml})\end{array}$ & $\begin{array}{l}20 \\
20\end{array}$ & $\begin{array}{l}321 \pm 26 \\
616 \pm 133\end{array}$ & $\begin{array}{l}234 \pm 72 \\
246 \pm 28\end{array}$ & $\begin{array}{c}94 \pm 50 \\
-369 \pm 107\end{array}$ \\
\hline
\end{tabular}

Fat cells from euthyroid and hypothyroid rats were incubated in $1 \mathrm{ml}$ of Krebs-Ringer phosphate buffer containing $4 \%$ serum albumin. Incubations were performed with insulin concentrations of $2.4 \mathrm{mU} / \mathrm{ml}$ for each of the glucose concentrations indicated. The incubation was initiated by the addition of the fat cells to medium containing the above agents and was terminated $1 \mathrm{~h}$ later by the addition of $0.2 \mathrm{ml}$ of $2 \mathrm{~N} \mathrm{HCl}$. The values presented are the means of three experiments performed in duplicate on different days.

of insulin to inhibit theopylline-stimulated lipolysis in isolated fat cells from euthyroid and hypothyroid rats. As reported previously (16), the cells from the latter rats were poorly responsive to the lipolytic agent. Rates of glycerol release from these cells treated with 2 and $5 \mathrm{mM}$ theophylline were similar to the glycerol release observed in control cells incubated with 0.25 and $0.5 \mathrm{mM}$ theophylline, respectively. Control cells exhibited maximal lipolytic rates at $5 \mathrm{mM}$ theophylline compared with the $2 \mathrm{mM}$ condition. Although these differences complicate interpretations somewhat, it can be seen that insulin effectively inhibited glycerol release in both cell types (Table III). No significant difference in the decrement of glycerol release due to insulin was observed between control cells treated with $0.25 \mathrm{mM}$ theophylline and cells from hypothyroid rats incubated with $2 \mathrm{mM}$ theophylline. Other experiments indicated that sensitivity to lower insulin concentrations was also largely intact (not shown). The level of cyclic AMP in these cells at 2 min of incubation were also studied (Fig. 3). Control cells exhibited higher cyclic AMP levels under all conditions, compared with cells derived from hypothyroid rats $(P$ $<0.05)$. Insulin had no significant effect on cyclic AMP levels except in control cells incubated with $2 \mathrm{mM}$ theophylline, where a significant decrease due to insulin was observed $(P<0.05)$. Most striking, however, was the lack of correlation between cyclic AMP levels and lipolytic rates in the two cell types. Thus, cyclic AMP levels were lower in cells from hypothyroid rats, which released $3.4 \mathrm{mmol}$ glycerol $/ 10^{6}$ cells, than in control cells, which exhibited $0.28 \mathrm{mmol}$ glycerol $/ 10^{6}$ cells.
The pattern of glucose metabolism in isolated soleus muscles was studied in order to gain insight into the effects of thyroid status on skeletal muscle metabolism. It has been demonstrated that conversion of $D$-[5${ }^{3} \mathrm{H}$ ]glucose to ${ }^{3} \mathrm{H}_{2} \mathrm{O}$ represents a useful index of glycolytic flux in such muscles $(13,17)$. Table IV illustrates that the conversion of $\mathrm{D}-\left[5-{ }^{3} \mathrm{H}\right]$ glucose to both labeled glycogen and $\mathrm{H}_{2} \mathrm{O}$ are similar in muscles derived from euthyroid and hypothyroid rats when incubated in the absence of insulin. A supermaximal concentration of insulin provoked a ninefold increase in labeled glycogen production as well as a much smaller effect on ${ }^{3} \mathrm{H}_{2} \mathrm{O}$ production in control soleus muscles. In contrast, no stimulation of ${ }^{3} \mathrm{H}_{2} \mathrm{O}$ production by insulin was observed in muscles derived from hypothyroid rats. A significant decrease in soleus muscle $\left[{ }^{3} \mathrm{H}\right]$ glycogen production in the presence of insulin was also observed, compared with that found in muscles from euthyroid rats. Similar defective responses to lower concentrations of insulin $(300 \mu \mathrm{U} / \mathrm{ml}$ and $2 \mathrm{mU} / \mathrm{ml})$ were also observed (not shown).

To determine whether the blunted responsiveness to insulin observed in soleus muscles from hypothyroid rats was due to a defect in the insulin effector system, insulin action on muscle hexose transport system activity was monitored using both 2-deoxyglucose and $\mathrm{L}$-arabinose as substrates. Table V illustrates the uptake of $2-\left[{ }^{3} \mathrm{H}\right]$ deoxyglucose in isolated muscles over a 15 min period in the presence and absence of a submaximal and maximal dose of insulin. No significant difference in deoxyglucose uptake could be observed between muscle types in the absence of insulin. In- 


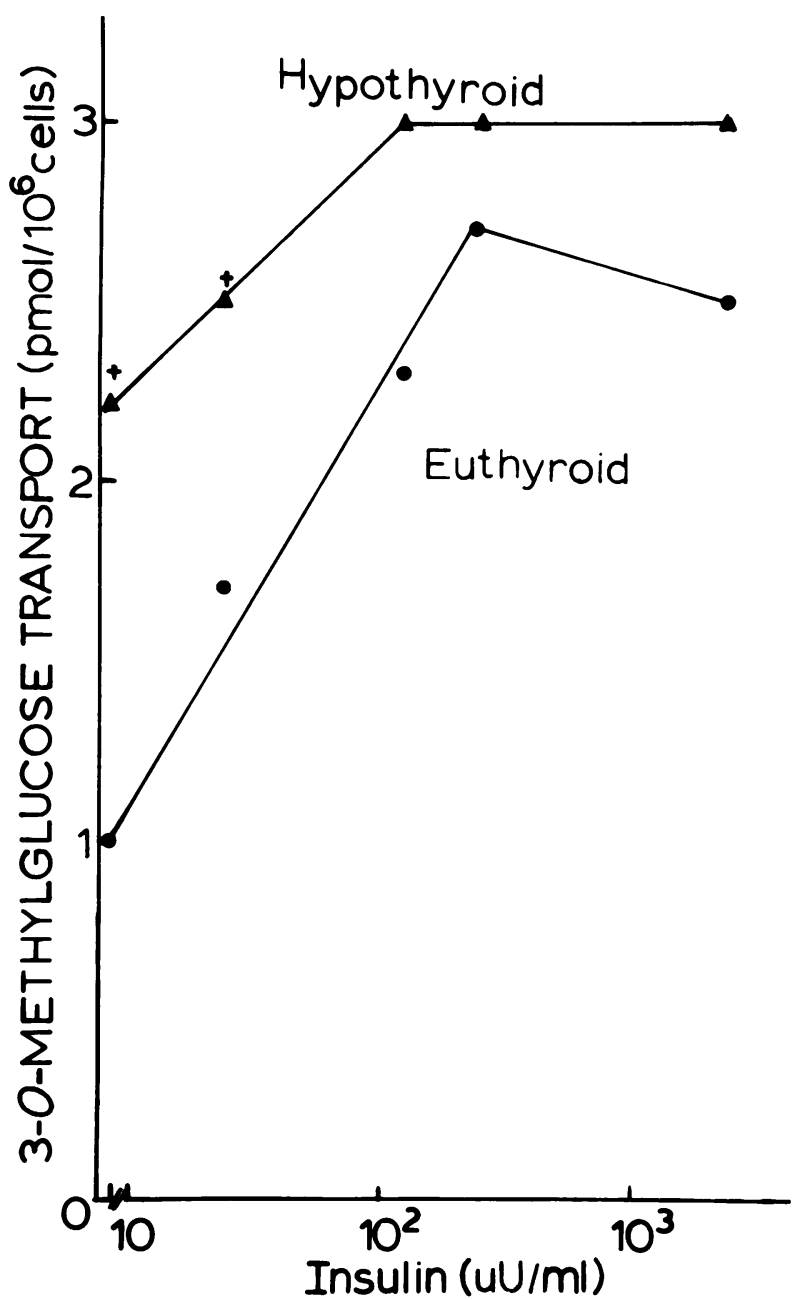

FIGURE 2 Insulin action on 3-O-methylglucose transport in fat cells derived from normal and hypothyroid rats. Fat cells ( $1-4 \times 10^{5}$ cells/tube) were incubated with or without the indicated concentrations of insulin for $10 \mathrm{~min}$ in KrebsRinger phosphate buffer at $37^{\circ} \mathrm{C}$ before addition of $50 \mu \mathrm{M}$ $\left[3-\mathrm{O}-{ }^{3} \mathrm{H}\right]$ methylglucose and assay of uptake for $10 \mathrm{~s}$. The amount of hexose uptake observed in the presence of $50 \mu \mathrm{M}$ cytochalasin B was taken as diffusion and was subtracted from the other values obtained. The data presented are the means of four experiments performed in triplicate on different days. Asterisks denote that difference between hypothyroid and control values is statistically significant $(P<0.05)$.

sulin markedly enhanced deoxyglucose uptake by soleus muscles derived from both groups of animals. However, the mean percent increments in deoxyglucose uptake due to 1.08 or $108 \mathrm{mU} / \mathrm{ml}$ insulin were not significantly different between muscles from euthyroid or hypothyroid rats. Studies not illustrated indicated deoxyglucose uptake was linear in soleus muscles for over $15 \mathrm{~min}$.

To corroborate this result using another hexose analogue, $\mathrm{L}-\left[{ }^{14} \mathrm{C}\right]$ arabinose was used in similar studies. Fig. 4 illustrates the time-course of $\mathrm{L}-\left[{ }^{14} \mathrm{C}\right]$ arabinose
TABLE II

Binding of ${ }^{125}$ I-Insulin to Adipocytes from Euthyroid and Hypothyroid Rats

\begin{tabular}{|c|c|c|}
\hline \multirow{2}{*}{$\begin{array}{l}{ }^{125} \mathrm{I} \text {-Insulin } \\
\text { concentration }\end{array}$} & \multicolumn{2}{|c|}{ 125I-Insulin bound } \\
\hline & Euthyroid & Hypothyroid \\
\hline & \multicolumn{2}{|c|}{ fmol/10 cells } \\
\hline $0.2 \mathrm{nM}$ & $0.023 \pm 0.003$ & $0.024 \pm 0.005$ \\
\hline $1.8 \mathrm{nM}$ & $0.17 \pm 0.03$ & $0.18 \pm 0.03$ \\
\hline $16 \mathrm{nM}$ & $1.2 \pm 0.2$ & $1.2 \pm 0.2$ \\
\hline $1.6 \mu \mathrm{M}$ & $74 \pm 12$ & $84 \pm 9$ \\
\hline
\end{tabular}

${ }^{125}$ I-Insulin tracer $\left(2 \times 10^{-10} \mathrm{M}\right)$ was incubated with fat cells $\left(2 \times 10^{5}, 0.5 \mathrm{ml} /\right.$ tube $)$ in the presence or absence of unlabeled insulin to the final insulin concentration indicated below. The incubation was terminated by the addition of $3.0 \mathrm{ml}$ ice-cold Krebs-Ringer phosphate buffer containing $0.1 \%$ albumin and the mixture was rapidly filtered under vacuum through a Whatman GFA filter. The filter was quickly washed with $9.0 \mathrm{ml}$ additional ice-cold buffer, dried, and counted. Each point was determined in triplicate. The data given above represent the mean $\pm \mathrm{SE}$ of three experiments performed on separate days.

uptake in isolated soleus muscles over a 90 -min period. In control muscles, uptake of this hexose increased steadily over the entire period of incubation, while the known transport inhibitor cytochalasin B significantly decreased uptake. Insulin at $3 \mathrm{mU} / \mathrm{ml}$ markedly activated $\mathrm{L}_{-}\left[{ }^{14} \mathrm{C}\right]$ arabinose transport in soleus muscles, and this increased accumulation of label was observed throughout the experiment. Equilibration of the label thus did not occur in control and cytochalasin Btreated muscles, indicating that $\mathrm{L}-\left[{ }^{14} \mathrm{C}\right]$ arabinose is a slowly transported glucose analogue in this system. Table VI depicts the results of a series of experiments where insulin action on $\mathrm{L}-\left[{ }^{14} \mathrm{C}\right]$ arabinose was assessed in soleus muscles from euthyroid and hypothyroid rats. No difference due to thyroid status in hexose transport rates was observed in the presence or absence of hormone.

The stimulatory action of insulin on glucose conversion to glycogen reflects the capability of insulin to both activate hexose transport and to elicit the conversion of glycogen synthase $D$ to the $I$ form (18). The decreased flux observed in muscles from hypothyroid rats of glucose into glycogen in response to insulin in the face of unimpaired insulin action on hexose transport (Tables IV and VI) could then result from defective synthase activation. We therefore studied the effect of insulin on glycogen synthase activity in soleus muscles incubated in the absence of medium glucose (Table VII). Total glycogen synthase activity was estimated in muscle homogenates supplemented with $10 \mathrm{mM}$ glucose-6-phosphate, and synthase $I$ activity was monitored in the absence of this hexose phosphate. No differences in the percentage of synthase activity 
TABLE III

Antilipolytic Effect of Insulin on Fat Cells Derived from Euthyroid and Hypothyroid Rats

\begin{tabular}{|c|c|c|c|c|}
\hline \multirow[b]{2}{*}{$\begin{array}{l}\text { Theophylline } \\
\text { concentration }\end{array}$} & \multicolumn{2}{|c|}{ Euthyroid } & \multicolumn{2}{|c|}{ Hypothyroid } \\
\hline & $\begin{array}{l}\text { Without } \\
\text { insulin }\end{array}$ & $\begin{array}{l}\text { Mean decrement } \\
\text { due to } 2.4 \mathrm{mU} / \mathrm{ml} \\
\text { insulin }\end{array}$ & $\begin{array}{l}\text { Without } \\
\text { insulin }\end{array}$ & $\begin{array}{l}\text { Mean decrement } \\
\text { due to } 2.4 \mathrm{mU} / \mathrm{ml} \\
\text { insulin }\end{array}$ \\
\hline$m M$ & \multicolumn{2}{|c|}{$\mathrm{mmol} / 10^{\circ} \mathrm{cells}$} & \multicolumn{2}{|c|}{$\mathrm{mmol} / 10^{6} \mathrm{cells}$} \\
\hline 0 & $0.28 \pm 0.08$ & $0.22 \pm 0.062$ & $0.20 \pm 0.083$ & $0.054 \pm 0.028$ \\
\hline 0.1 & $0.83 \pm 0.15$ & $0.53 \pm 0.16$ & $0.22 \pm 0.078$ & $0.055 \pm 0.035$ \\
\hline 0.25 & $2.6 \pm 0.55$ & $2.2 \pm 0.43$ & $0.39 \pm 0.14$ & $0.12 \pm 0.12$ \\
\hline 0.50 & $3.8 \pm 0.64$ & $3.1 \pm 0.47$ & $0.66 \pm 0.28$ & $0.42 \pm 0.25$ \\
\hline 2.0 & $6.4 \pm 1.0$ & $2.6 \pm 0.45$ & $2.3 \pm 0.62$ & $1.6 \pm 0.50$ \\
\hline 5.0 & $6.8 \pm 0.85$ & $0.55 \pm 0.54$ & $3.40 \pm 0.66$ & $1.4 \pm 0.066$ \\
\hline
\end{tabular}

Fat cells were incubated in $1 \mathrm{ml}$ of Krebs-Ringer phosphate buffer containing $4 \%$ bovine serum albumin for $2 \mathrm{~h}$ at $37^{\circ} \mathrm{C}$. The indicated concentrations of theophylline were added at the start of the experiment in the presence or absence of $2.4 \mathrm{mU} / \mathrm{ml}$ insulin. At the end of the incubation period the fat cells were allowed to float, and 50- $\mu$ l aliquots of medium were taken for analysis of glycerol. The values presented are the means \pm standard error of total glycerol or the decrement due to insulin of three separate experiments performed in triplicate.

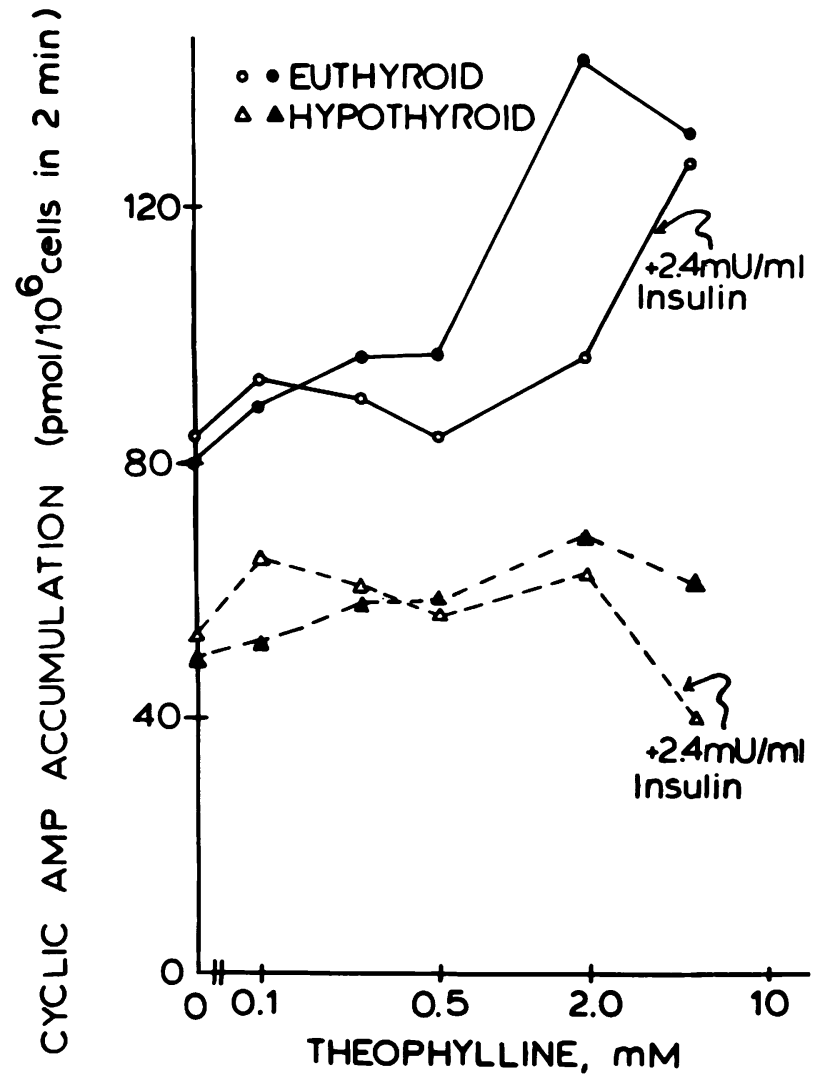

FIGURE 3 Effect of insulin on theophylline-stimulated cyclic AMP accumulation of fat cells from euthyroid and hypothyroid rats. Fat cells from euthyroid (circles) or hypothyroid (triangles) rats were incubated in $1 \mathrm{ml}$ of Krebs-Ringer phosphate buffer containing $4 \%$ bovine serum albumin at $37^{\circ} \mathrm{C}$ that was observed to be in the $I$ form, or in insulin action on conversion of $D$ to $I$ form in soleus muscles could be observed due to thyroid status of the rats (Table VII).

\section{DISCUSSION}

The data presented in this report demonstrate a strikingly similar alteration in the carbohydrate utilization of both adipocytes and soleus muscles due to hypothyroidism in rats. This alteration in the hypothyroid state is expressed as a decreased insulin responsiveness of D-glucose utilization in these tissues under conditions where basal glucose metabolism is not significantly different from euthyroid values. However, all of the results obtained are consistent with the concept that the cellular insulin effector systems in these tissues are not defective in the hypothyroid state, but rather that one or more intracellular enzymes involved in glucose metabolism are diminished. The following data support this conclusion: (a) hexose transport system activity measured by nonmetabolizable hexose uptake in the presence of insulin is not different in fat cells or soleus muscles from euthyroid vs. hypothyroid

with the indicated concentrations of theophylline in the absence (filled symbols) or presence (open symbols) of $24 \mathrm{mU} / \mathrm{ml}$ of insulin. The incubation was initiated by the addition of the fat cells to medium containing the above agents and was terminated 2 min later by the addition of $0.1 \mathrm{ml}$ of $2 \mathrm{~N} \mathrm{HCl}$ The tubes were then boiled for $1 \mathrm{~min}$ and cooled to room temperature in $20-\mu$ aliquot of cells plus medium. The values presented are the means of three separate experiments performed in triplicate. 
TABLE IV

Effects of Insulin on D-[5- $\left.{ }^{3} \mathrm{H}\right]$ Glucose Conversion to Glycogen and $\mathrm{H}_{2} \mathrm{O}$ in Soleus Muscles of Euthyroid and Hypothyroid Rats

\begin{tabular}{lcccc}
\hline & $\begin{array}{c}{\left[5^{-3} \mathrm{H}\right] \text { Glucose }} \\
\text { conversion } \\
\text { to glycogen }\end{array}$ & $\begin{array}{c}\text { Number of } \\
\text { muscles } \\
\text { studied }\end{array}$ & $\begin{array}{c}\text { [5-3 } \mathrm{H}] \mathrm{Glucose} \\
\text { conversion } \\
\text { to } \mathrm{H}_{2} \mathrm{O}\end{array}$ & $\begin{array}{c}\text { Number of } \\
\text { muscles } \\
\text { studied }\end{array}$ \\
\hline & nmol/mg & & $n$ nmol/mg & \\
Euthyroid & & & & \\
$\quad \begin{array}{l}\text { Control } \\
\text { Insulin }(77 \mathrm{mU} / \mathrm{ml})\end{array}$ & $0.30 \pm 0.04$ & 11 & $2.2 \pm 0.2$ & 10 \\
Hypothyroid & $2.6 \pm 0.3$ & 11 & $2.7 \pm 0.2$ & 10 \\
$\begin{array}{l}\text { Control } \\
\text { Insulin }\end{array}$ & $0.27 \pm 0.03$ & 11 & $2.0 \pm 0.2$ & 10 \\
\hline
\end{tabular}

Soleus muscles were incubated with continuous oxygenation in $2.5 \mathrm{ml} \mathrm{Krebs-Ringer}$ bicarbonate buffer containing $2 \%$ bovine serum albumin for $30 \mathrm{~min}$ in the presence or absence of $77 \mathrm{mU} / \mathrm{ml}$ insulin. All vessels then received $4 \mathrm{mM} \mathrm{D-}\left[5{ }^{-3} \mathrm{H}\right]$ glucose $(1-2$ $\mu \mathrm{Ci} / \mathrm{ml}) ; 15 \mathrm{~min}$ later, muscles were assayed for labeled glycogen, and $0.5 \mathrm{ml}$ of medium was lyophilized to determine labeled $\mathrm{H}_{2} \mathrm{O}$. Values presented are the means $\pm S E$.

* Significantly different from euthyroid value $(P<0.01)$.

rats under conditions wherein glucose metabolism was substantially diminished in the hypothyroid state (Fig. 3 and Table VI); (b) insulin action on other cellular functions, such as adipocyte lipolysis (Table III) and soleus muscle glycogen synthase (Table VII) in the absence of medium glucose, was normal in the hypothyroid state; and $(c){ }^{125}$ I-insulin binding to cell sur-

TABLE V

2-Deoxyglucose Uptake in Soleus Muscles of Hypothyroid and Euthyroid Rats

\begin{tabular}{lrcc}
\hline \multicolumn{1}{c}{ Condition } & $\begin{array}{c}\text { Number of } \\
\text { muscles } \\
\text { studied }\end{array}$ & $\begin{array}{c}\left.\text { [ }{ }^{3} \mathrm{H}\right] \text { Deoxy- } \\
\text { glucose uptake }\end{array}$ & $\begin{array}{c}\text { Increment } \\
\text { due to } \\
\text { insulin }\end{array}$ \\
\hline & & pmol/mg muscle & $\%$ \\
Euthyroid & & & \\
$\quad$ Control & 10 & $2.07 \pm 0.7$ & \\
$\quad$ Insulin $(1.08 \mathrm{mU} / \mathrm{ml})$ & 5 & $4.46 \pm 0.8$ & 115 \\
Insulin $(108 \mathrm{mU} / \mathrm{ml})$ & 6 & $7.73 \pm 1$ & 273 \\
& & & \\
Hypothyroid & 11 & $1.33 \pm 0.4$ & \\
$\quad$ Control & 6 & $3.45 \pm 0.4$ & 159 \\
Insulin $(1.08 \mathrm{mU} / \mathrm{ml})$ & 6 & $6.0 \pm 0.8$ & 351 \\
Insulin $(108 \mathrm{mU} / \mathrm{ml})$ & & & \\
\hline
\end{tabular}

All muscles were incubated for $30 \mathrm{~min}$ at $37^{\circ} \mathrm{C}$ with continuous oxygenation in $2.5 \mathrm{ml}$ Krebs-Ringer bicarbonate buffer containing $2 \%$ albumin and $1.6 \mathrm{mM}$ pyruvate in the presence or absence of 1.08 or $108 \mathrm{mU} / \mathrm{ml}$ insulin. The addition of $0.16 \mathrm{mM}$ $2-\left[{ }^{3} \mathrm{H}\right]$ deoxyglucose was made to all vessels; 15 min later, muscles were rinsed twice in ice-cold buffer and assayed for accumulated label. All values were corrected for extracellular label by the subtraction of the amount of accumulated label in muscles exposed to $80 \mu \mathrm{M}$ cytochalasin $\mathrm{B}$. Values are the means $\pm S E$ of the number of muscles indicated or the percent increments due to insulin. face receptors was unimpaired in adipocytes derived from hypothyroid rats (Table II). Thus the data lead to the conclusion that the cellular locus responsible for the apparent insulin resistance observed in these studies is one or more intracellular enzymes involved in glucose metabolism.

It should be noted that the impact of the hypothyroid state on isolated adipocyte metabolism appears greater in magnitude than on the isolated soleus muscle system, inasmuch as the latter did not appear to be af-

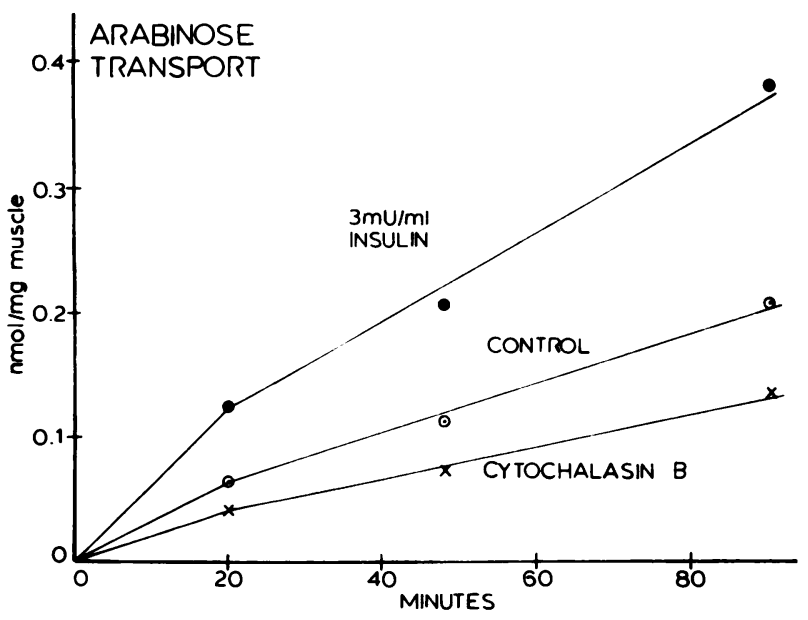

FIgURE 4 Cytochalasin B-sensitive arabinose uptake in isolated soleus muscles. Soleus muscles were incubated for 15 min at $24^{\circ} \mathrm{C}$ with continuous oxygenation in $2.5 \mathrm{ml}$ KrebsRinger bicarbonate buffer containing $2 \%$ albumin in the presence or absence of $3 \mathrm{mU} / \mathrm{ml}$ insulin or $50 \mu \mathrm{M}$ cytochalasin B. Addition of $0.5 \mathrm{mM} \mathrm{L}-\left[{ }^{14} \mathrm{C}\right]$ arabinose was made to all vessels, and at the indicated times of incubation muscles were rinsed twice for $5 \mathrm{~min}$ each in ice-cold buffer and assayed for accumulation of label. 
TABLE VI

Arabinose Uptake in Soleus Muscles of Hypothyroid and Euthyroid Rats

\begin{tabular}{|c|c|c|c|}
\hline & $\begin{array}{c}\text { Number of } \\
\text { muscles } \\
\text { studied }\end{array}$ & $\begin{array}{l}{\left[{ }^{[4} \mathrm{C}\right] \text { Arabinose }} \\
\text { uptake }\end{array}$ & $\begin{array}{l}\text { Mean increment } \\
\text { due to insulin }\end{array}$ \\
\hline & & nmollmg muscle & $\%$ \\
\hline \multicolumn{4}{|l|}{ Euthyroid } \\
\hline Control & 7 & $0.025 \pm 0.006$ & \multirow[t]{2}{*}{$280 \pm 80$} \\
\hline Insulin $(3 \mathrm{mU} / \mathrm{ml})$ & 7 & $0.086 \pm 0.009$ & \\
\hline \multicolumn{4}{|l|}{ Hypothyroid } \\
\hline Control & 8 & $0.023 \pm 0.004$ & \multirow[t]{2}{*}{$456 \pm 143$} \\
\hline Insulin $(3 \mathrm{mU} / \mathrm{ml})$ & 8 & $0.091 \pm 0.007$ & \\
\hline
\end{tabular}

Soleus muscles were incubated for $15 \mathrm{~min}$ at $24^{\circ} \mathrm{C}$ with continuous oxygenation in $2.5 \mathrm{ml}$ Krebs-Ringer bicarbonate buffer containing $2 \%$ albumin in the presence or absence of $3 \mathrm{mU} / \mathrm{ml}$ insulin. Addition of $0.5 \mathrm{mM} \mathrm{L}-\left[{ }^{14} \mathrm{C}\right]$ arabinose was made to all vessels; $45 \mathrm{~min}$ later, muscles were rinsed twice for $5 \mathrm{~min}$ each in ice-cold buffer and assayed for accumulation of label. All values were corrected for extracellular $\mathrm{L}-\left[{ }^{14} \mathrm{C}\right]$ arabinose by subtracting the amount of label accumulated in the presence of cytochalasin $B$. Values presented are the means $\pm S E$ number of muscles shown.

fected in respect to glucose transport rates. However, insulin responsiveness of glucose conversion to glycogen was inhibited by almost $50 \%$ in the hypothyroid state, while glycolytic flux stimulation by the hormone was completely inhibited. Supermaximal concentrations of insulin $(77 \mathrm{mU} / \mathrm{ml})$ were used to test maximal responsiveness of the system rather than insulin sensitivity. In experiments not presented, responsiveness to lower concentrations of insulin approaching the physiological range was also inhibited in this soleus muscle preparation. We do not yet know whether these observations are physiologically important in the intact animal. However, the diminished muscle insulin responsiveness reported here is highly statistically significant and parallels the adipocyte defect in hypothyroidism, indicating a potentially important physiological basis.

Our data documenting decreased glucose metabolism in adipocytes treated with insulin due to hypothyroidism conflict with the results of Correze et al. $(19,20)$, who found increased adipocyte glucose metabolism in thyroidectomized rats. Rats were rendered hypothyroid for periods similar to those employed in our studies before experiments were performed. However, a key difference in those studies is the very young age and hence weight $(60-80-\mathrm{g}$ rats) at which thyroidectomy was performed. Growth of the animals is markedly affected by hypothyroidism at this early stage of development, and interpretations of results obtained in such studies are complicated by this problem. In the experiments described in this report,
TABLE VII

Glycogen Synthase Activity in the Soleus Muscle of Hypothyroid and Euthyroid Rats

\begin{tabular}{lcc}
\hline \multicolumn{1}{c}{ Condition } & $\begin{array}{c}\text { Glycogen } \\
\text { synthase I }\end{array}$ & $\begin{array}{c}\text { Number of } \\
\text { muscles } \\
\text { studied }\end{array}$ \\
\hline & $\%$ & \\
$\quad$ Hypothyroid & & \\
$\quad$ Control & $29.3 \pm 2.9$ & 8 \\
$\quad$ Insulin $(77 \mathrm{mU} / \mathrm{ml})$ & $38.7 \pm 2.4$ & 9 \\
Euthyroid & & \\
$\quad$ Control & $28.6 \pm 1.4$ & 9 \\
$\quad$ Insulin $(77 \mathrm{mU} / \mathrm{ml})$ & $37.4 \pm 1.6$ & 9 \\
\hline
\end{tabular}

All muscles were incubated with continuous oxygenation for 30 min in Krebs-Ringer bicarbonate buffer with $2 \%$ albumin at $37^{\circ} \mathrm{C}$ in the presence or absence of $77 \mathrm{mU} / \mathrm{ml}$ insulin. The muscles were homogenized with Brinkmann Polytron (Brinkmann Instruments, Inc., Westbury, N. Y.) in $1 \mathrm{ml}$ of ice-cold $100 \mathrm{mM} \mathrm{KF}$ and $10 \mathrm{mM}$ EDTA, pH 7.0 for $20 \mathrm{~s}$; homogenates were centrifuged for $30 \mathrm{~min}$ at $3,000 \mathrm{~g}$. Supernatant aliquots of $30 \mu \mathrm{l}$ were added to the substrate, incubated for $10 \mathrm{~min}$ at $30^{\circ} \mathrm{C}$, and each sample was spotted on filter paper, washed, and assayed for label accumulation. Glycogen synthase activity is expressed as a percentage of total activity (measured under the same conditions except for the addition of $10 \mathrm{mM}$ glucose6 -phosphate). Values are the means $\pm S E$ of the number of muscles indicated.

only fully mature animals weighing 175-200 g were subjected to the regimen producing hypothyroidism. In addition, the effects reported here do not relate to extraneous effects of the diet and propylthiouracil treatment on rats, inasmuch as injection of triiodothyronine was capable of reversing the metabolic defects observed (not illustrated).

An interesting observation in our studies was an increased D-glucose transport system activity in fat cells from hypothyroid rats (Fig. 2). This phenomenon was not observed in soleus muscles tested for hexose transport activity using 2-deoxyglucose and L-arabinose uptake rates (Tables $\mathrm{V}$ and VI). The increased transport activity in adipocytes from hypothyroid rats does not appear to have significant physiological relevance because basal adipocyte glucose metabolism was not increased in parallel with the increased transport rate. This lack of correlation can be attributed to the postulated decreased capacity of intracellular enzymes to metabolize glucose due to the hypothyroidism. It is tempting to speculate, however, that thyroid hormone deficiency leads to the modulation of a common membrane transduction system that regulates hexose transport and is also responsive to insulin. Modulation of the transmembrane signaling between the $\beta$-receptor and the adeylate cyclase has been recently proposed as the basis for the altered catecholomine-stimulated lipolytic response of fat cells from hypothyroid rats (16). 
A series of studies by Schoenle et al. (21-23) have demonstrated increased adipocyte hexose transport activity in hypophysectomized rats. Administration of growth hormone to these animals reversed the elevated transport activity to levels observed in control adipocytes. Glucose transport activity in the presence of insulin was similar in adipocytes derived from both control and hypophysectomized rats, however. These data are remarkably similar to our observations with hypothyroid rats and thyroid hormone administration. Thyroid hormone administration to hypophysectomized rats did not decrease glucose transport in the studies of Schoenle et al. (21-23). However, it seems possible that thyroid hormone action may require the presence of growth hormone to act. Taken together, the available data indicate that both growth hormone and thyroid hormone play significant roles in the regulation of glucose transport and its modulation by insulin.

\section{ACKNOWLEDGMENTS}

These studies were supported by grants AM-17893 and HD11343 from the U. S. Public Health Service.

\section{REFERENCES}

1. Danforth, E. S., A. G. Burger, and C. Wimpfheimer. 1978. Nutritionally-induced alterations in thyroid hormone metabolism and thermogenesis. Experientia. (Basal) 32(Suppl.): 213-217.

2. Wimpfheimer, C., E. Saville, M. J. Voirol, E. J. Danforth, and A. G. Burger. 1979. Starvation-induced decreased sensitivity of resting metabolic rate to triiodothyronine. Science (Wash. D. C.) 205: 1272-1273.

3. Goswami, A., and I. N. Rosenberg. 1978. Thyroid hormone modulation of epinephrine-induced lipolysis in rat adipocytes: a possible role of calcium. Endocrinology. 103: 2223-2233.

4. Deykin, K., and M. Vaughn. 1963. Release of free fatty acids by adipose tissue from rats treated with triiodothyronine or propylthiouracil. J. Lipid Res. 4: 200.

5. Armstrong, K. J., J. E. Stouffer, R. G.VanInwegen, W. J. Thompson, and G. A. Robison. 1974. Effects of thyroid hormone deficiency on cyclic adenosine $3^{\prime}: 5^{\prime}$-monophosphate and control of lipolysis in fat cells. J. Biol. Cell. 249: 4226.

6. Rodbell, M. 1964. Metabolism of isolated fat cells. I. Effects of hormones on glucose metabolism and lipolysis. J. Biol. Chem. 239: 375-380.

7. Gliemann, J. 1965. Insulin-like activity of dilute human serum assayed by an isolated adipose cell method. Diabetes. 14: 643-649.
8. Gilman, A. G. 1970. A protein binding assay for adenosine 3':5'-cyclic monophosphate.Proc. Natl. Acad. Sci. U. S. A 67: 305-312.

9. Brown, B. L., J. D. M. Albano, R. P. Elkins, A. M. Sgherzi, and W. Tampion. 1971. A simple and sensitive saturation assay method for the measurement of adenosine 3':5'-cyclic monophosphate. Biochem. J. 121: 561-562.

10. Fain, J. N., N. Reed, and R. Saperstien. 1967. The isolation and metabolism of brown fat cells. J. Biol. Chem. 242: 1887- 1894.

11. LeMarchand, Y., B. Jeanrenaud, and P. Freychet. 1978. Insulin action in skeletal muscle of lean and obese mice. Am. J. Physiol. 3: E348-E358.

12. Cuendet, G. S., E. G. Loten, B. Jeanrenaud, and A. E. Renold. 1976. Decreased basal, noninsulin-stimulated glucose uptake and metabolism by skeletal soleus muscle isolated from obese-hyperglycemic $(o b / o b)$ mice. J. Clin. Invest. 58: 1078-1088.

13. Brown, D., and C. J. Garratt. 1964. A simple method for determining total glucose utilization by isolated adipocytes using [5- $\left.{ }^{3} \mathrm{H}\right]$ glucose. Anal. Biochem. 61: 314-322.

14. Czech, M. P., and J. N. Fain. 1972. Antagonism of insulin action on glucose metabolism in white fat cells by dexamethasone. Endocrinology. 91: 518-522.

15. Czech, M. P. 1976. Regulation of the D-glucose transport system in isolated fat cells. Mol. Cell. Biochem. 2: 51-63.

16. Malbon, C. C., F. J. Moreno, R. J. Cabelli, and J. N. Fain. 1978. Fat cell adenylate cyclase and beta-adrenergic receptors in altered thyroid states. J. Biol. Chem. 253: $671-678$

17. Czech, M. P., D. K. Richardson, S. G. Becker, C. G. Walters, W. Gitomer, and J. Heinrich. 1978. Insulin response in skeletal muscle and fat cells of the genetically obese Zucker rat. Metab. Clin. Exp. 27: 1967-1981.

18. Lawrence, J. C., Jr., J. J. Guinovart, and J. Larner. 1977. Activation of rat adipocyte glycogen synthase by insulin. J. Biol. Chem. 252: 444-450.

19. Correze, R. A., and J. Nunez. 1976. Cyclic nucleotide phosphodiesterases, insulin and thyroid hormones. Mol. Cell. Endocr. 5: 67-79.

20. Correze, C., E. Krug, M. Verhaegen, and J. Nunez. 1979. Regulation in adipocytes. Independent effects of thyroid hormones, cyclic AMP and insulin on the uptake of deoxyD-glucose. Biochim. Biophys. Acta. 574: 164-172.

21. Schoenle, E. J., J. Zaph, and E. R. Froesch. 1979. Receptor binding and effects of insulin and NSILA-S on glucose transport and metabolism in adipocytes from hypophysectomized rats. Diabetologia. 16: 41-46.

22. Schoenle, E. J., J. Zapf, and E. R. Froesch. 1979. Effects of insulin on glucose metabolism and glucose transport in fat cells of hormone-treated hypophysectomized rats: evidence that growth hormone restricts glucose transport. Endocrinology. 105: 1237-1242.

23. Schoenle, E., J. Zapf, and E. R. Froesch. 1979. Transport and metabolism of fructose in fat cells of normal and hypophysectomized rats. Am. J. Physiol. 6: E325-E330. 